\title{
Submucosal tunneling techniques: current perspectives
}

This article was published in the following Dove Press journal:

Clinical and Experimental Gastroenterology

5 April 2014

Number of times this article has been viewed

\author{
Hideki Kobara' \\ Hirohito Mori' \\ Kazi Rafiq ${ }^{2}$ \\ Shintaro Fujihara' \\ Noriko Nishiyama' \\ Maki Ayaki' \\ Tatsuo Yachida' \\ Tae Matsunaga' \\ Johji Tani' \\ Hisaaki Miyoshi' \\ Hirohito Yoneyama' \\ Asahiro Morishita' \\ Makoto Oryu' \\ Hisakazu Iwama ${ }^{3}$ \\ Tsutomu Masaki' \\ 'Department of Gastroenterology \\ and Neurology, ${ }^{2}$ Department of \\ Pharmacology, ${ }^{3}$ Life Science Research \\ Center, Faculty of Medicine, Kagawa \\ University, Miki-cho, Kita-Gun, \\ Kagawa, Japan
}

\begin{abstract}
Advances in endoscopic submucosal dissection include a submucosal tunneling technique, involving the introduction of tunnels into the submucosa. These tunnels permit safer offset entry into the peritoneal cavity for natural orifice transluminal endoscopic surgery. Technical advantages include the visual identification of the layers of the gut, blood vessels, and subepithelial tumors. The creation of a mucosal flap that minimizes air and fluid leakage into the extraluminal cavity can enhance the safety and efficacy of surgery. This submucosal tunneling technique was adapted for esophageal myotomy, culminating in its application to patients with achalasia. This method, known as per oral endoscopic myotomy, has opened up the new discipline of submucosal endoscopic surgery. Other clinical applications of the submucosal tunneling technique include its use in the removal of gastrointestinal subepithelial tumors and endomicroscopy for the diagnosis of functional and motility disorders. This review suggests that the submucosal tunneling technique, involving a mucosal safety flap, can have potential values for future endoscopic developments.
\end{abstract}

Keywords: submucosal endoscopy, submucosal tunneling method, natural orifice transluminal endoscopic surgery, peroral endoscopic myotomy, gastrointestinal subepithelial tumor, functional and motility disorders

\section{Introduction}

Minimally invasive endoscopic resection is gradually displacing conventional surgical interventions. Endoscopic therapy has developed from the strip biopsy ${ }^{1}$ to direct resection with a snare to endoscopic mucosal resection (EMR). ${ }^{2}$ EMR has several disadvantages, however, including the high rates of residual tumor tissue and tumor recurrence. In contrast, endoscopic submucosal dissection (ESD), first introduced in 1999, allows the direct dissection of the submucosa. ${ }^{3}$ ESD is now the gold standard for performing en bloc resection of superficial tumors in the gastrointestinal (GI) tract. $^{4}$

ESD is more accurate for histological diagnoses than EMR, as well as reducing tumor recurrence rates. Its initial outcomes and rapid development have resulted in more widespread use of ESD. ${ }^{5}$ Historically, successful new interventional procedures such as ESD have been developed to decrease invasiveness. The development of natural orifice transluminal endoscopic surgery (NOTES) ${ }^{6}$ has revealed the clinical need for a new flexible endoscopic platform. Preclinical investigations have shown the success of NOTES. ${ }^{7-10}$ Among the new endoscopic interventions based on ESD is the submucosal tunneling technique, which involves the introduction into the submucosa of tunnels that permit a safer offset entry into the peritoneal cavity for NOTES.
Correspondence: Hideki Kobara Department of Gastroenterology and Neurology, Faculty of Medicine, Kagawa University, I750-I Ikenobe, Miki-cho, Kita-Gun, Kagawa 76I-0793, Japan

Tel +81878912156

Fax +81878912158

Email kobara@med.kagawa-u.ac.jp 
This method, developed at the Mayo Clinic, was initially described as submucosal endoscopy with a mucosal flap safety valve (SEMF). ${ }^{11}$

This SEMF method was adapted for esophageal myotomy, ${ }^{12}$ culminating in its application to patients with achalasia, a method widely known as per oral endoscopic myotomy (POEM). ${ }^{13}$ The development of POEM has opened up a new discipline of submucosal endoscopic surgery. To date, several experimental studies have described the use of the submucosal tunneling technique for GI subepithelial lesions. Here, we discuss the current status of endoscopic submucosal tunneling techniques.

\section{Submucosal tunneling techniques NOTES}

NOTES is a peroral transgastric approach to the peritoneal cavity developed to reduce surgical invasiveness. ${ }^{7}$ The SEMF procedure was originally developed to provide safe access to the peritoneal cavity for NOTES. In the SEMF method, the submucosal layer is endoscopically tunneled into, with the resulting space used as an endoscopic path into deeper layers of the gut wall and an offset exit to the peritoneal cavity. Key to this method is the overlying mucosa, which serves as a sealant flap, minimizing the risk of soiling the body cavity with luminal contents and making it easier to close the entry point into the submucosal working space. Early clinical experience with SEMF yielded positive outcomes, showing that the submucosa can be transformed into a promising working space for flexible endoscopy. ${ }^{11}$

Experimental studies in pigs suggested additional indications for the submucosal tunneling technique in NOTES. For example, submucosal endoscopy with offset exit gastrotomy using the mucosal flap safety-valve technique may improve transgastric access for cholecystectomy. ${ }^{12}$ Moreover, the SEMF technique creating a submucosal tunnel provided safe entry into the mediastinum, resulting in transgastric access to the gallbladder and allowing the successful performance of epicardial coagulation within 30 minutes in four of five pigs. ${ }^{13}$ Follow-up endoscopy showed that the myotomy sites were completely sealed by the overlying mucosal flaps. In addition, the feasibility of a submucosal tunnel technique for transgastric peritoneal access and subsequent closure was shown to result in successful peritoneoscopy during NOTES. ${ }^{14}$

\section{POEM}

POEM is a novel endoscopic intervention, based on ESD and submucosal tunneling methods, for the treatment of esophageal achalasia. POEM was initially described in pigs ${ }^{15}$ and later in humans with achalasia. ${ }^{16}$ The methodology consists of the dissection and division of the inner circular muscle layer of the esophagus through a submucosal tunnel created endoscopically by a small proximal opening in the esophageal mucosa. Between 2010 and 2013, clinical trials in several countries showed that POEM yielded impressive results as a minimally invasive endoscopic treatment of achalasia (Table 1). ${ }^{17-22}$ Short-term analysis (median, 2.92 months; range, 1-5 months) showed that POEM was technically successful in almost $100 \%$ of patients, with no patient experiencing major complications $(0 \%)$ or requiring additional surgery $(0 \%) .{ }^{17-21}$ Moreover, clinical success rates for symptom remission were almost 100\% (range, 97.5\%-100\%). Most recently, an international, prospective, multicenter study showed 6- and 12-month symptom remission rates of $89 \%$ and $82 \%$, respectively. ${ }^{22}$ These findings indicated that POEM is a safe and effective treatment for esophageal achalasia, with good short- and long-term symptomatic relief rates and an acceptable rate of gastroesophageal reflux. Moreover, these results suggested that submucosal tunneling would make possible the safe performance of POEM.

Table I Clinical outcomes of POEM for esophageal achalasia

\begin{tabular}{|c|c|c|c|c|c|c|}
\hline Author (year) & Country & $\begin{array}{l}\text { \# of } \\
\text { patients }\end{array}$ & $\begin{array}{l}\text { Technical } \\
\text { success, \% (n) }\end{array}$ & $\begin{array}{l}\text { Clinical success for symptom } \\
\text { remission, \%, at follow-up } \\
\text { period (months) }\end{array}$ & $\begin{array}{l}\text { Major } \\
\text { complications, } \\
\%(n)\end{array}$ & $\begin{array}{l}\text { Additional } \\
\text { surgery, \% }\end{array}$ \\
\hline Inoue $(2010)^{16}$ & Japan & 17 & $100(17)$ & $100(5)$ & $0(0)$ & 0 \\
\hline Zhou $(201 \mathrm{I})^{17}$ & $\begin{array}{l}\text { People's Republic } \\
\text { of China }\end{array}$ & 42 & $100(42)$ & $97.6(2.5)$ & $0(0)$ & 0 \\
\hline von Renteln $(2012)^{18}$ & Germany & 16 & $100(16)$ & $100(3)$ & $0(0)$ & 0 \\
\hline Costamagna $(2012)^{19}$ & Italy & II & $91(10)$ & $100(1)$ & $0(0)$ & 0 \\
\hline Minami $(2014)^{20}$ & Japan & 28 & $100(28)$ & $100(3)$ & $0(0)$ & 0 \\
\hline Lee $(2013)^{21}$ & Korea & 13 & $100(13)$ & $100(3)$ & $0(0)$ & 0 \\
\hline von Renteln $(2013)^{22}$ & $\begin{array}{l}\text { Europe, } \\
\text { North America }\end{array}$ & 70 & $100(70)$ & $82.4(12)$ & $4.3(3)$ & 0 \\
\hline
\end{tabular}

Note: \#Major complications of perforation, mediastinitis, bleeding.

Abbreviation: POEM, per oral endoscopic myotomy. 
In summary, POEM has the advantages of being minimally invasive and of being viewed in the same way as open surgery. Thus, it has the potential to completely replace thoracoscopic Heller surgery and has strong prospects for other clinical applications.

However, POEM surgery is a difficult procedure to perform. Only those who have mastered ESD and have experience handling complications of ESD, such as hemorrhages and perforations, should perform POEM surgery.

\section{GI subepithelial tumors Endoscopic treatment using submucosal tunneling technique}

Although most subepithelial tumors (SETs) are benign, some have malignant potential. Resection of submucosal tumors (SMTs) would aid in diagnosis and may be curative. Several studies have evaluated the use of the submucosal tunneling technique to resect SETs. ${ }^{23-30}$ Generally, a submucosal tunnel is created endoscopically, starting approximately $5 \mathrm{~cm}$ proximal to the lesion. After careful submucosal dissection with carbon dioxide or air insufflation, the SETs are completely removed, and the mucosal entry site closed using endoclips. Endoscopic full-thickness resection using the submucosal tunnel technique in a patient under conscious sedation was first used successfully to treat small, intraluminal, subepithelial tumors. ${ }^{23}$ In the first case series describing the submucosal endoscopic tumor resection of tumors of the esophagus and cardia, two of nine patients required conversion to open surgery. ${ }^{24}$ Both of these patients had tumors that were too large $(60 \mathrm{~mm}$ and
$75 \mathrm{~mm}$, respectively) for safe endoscopic removal because of a loss of endoscopic overview. Therefore, the optimal indication for SETs may be submucosal tumors in the esophagus and cardia $\leq 4 \mathrm{~cm}$ in size. Submucosal tunneling endoscopic resection was performed successfully in 15 of 15 patients, with an en bloc resection rate of $100 \% .{ }^{25}$ Although one patient each experienced a pneumothorax and a pneumoperitoneum, both patients recovered uneventfully with proper conservative management. Several other studies of the submucosal tunneling method for GI SETs originating from the muscularis propria layer reported that en bloc resection was successful in $83.3 \%-100 \%$ of patients, and that complication rates were in the range of $0 \%-16.7 \%$ (Table 2 ). ${ }^{26-28}$ In contrast, standard ESD for SETs originating from the muscularis propria layer yielded a lower en bloc resection rate of $64 \%-75 \%$, suggesting the superiority of the submucosal tunneling technique. ${ }^{29,30}$ Moreover, this method is associated with lower rates of postoperative GI tract leakage and secondary infection.

However, care must be taken to prevent tumor seeding while performing endoscopic tumor resection for GI SETs in a narrow working space such as submucosal tunnels. Further studies are required to show whether this type of tumor resection is feasible and effective, particularly with regard to safe and complete resection of GI stromal tumors (GISTs) with an intact capsule.

The relative occurrence of GISTs and leiomyomas is dependent on anatomic location in the upper GI tract (Tables 2 and 3). In agreement with many previous reports, we found that GISTs were the most common SETs in the stomach, with

Table 2 Clinical outcomes of endoscopic treatment using submucosal tunneling technique for $\mathrm{Gl}$ subepithelial tumors

\begin{tabular}{|c|c|c|c|c|c|c|c|c|c|c|}
\hline $\begin{array}{l}\text { Author } \\
\text { (year) }\end{array}$ & Country & $\begin{array}{l}\text { \# of } \\
\text { patients }\end{array}$ & $\begin{array}{l}\text { Location } \\
\text { (details) }\end{array}$ & $\begin{array}{l}\text { Tumor } \\
\text { maximum } \\
\text { size (mm) }\end{array}$ & $\begin{array}{l}\text { Layer } \\
\text { of origin }\end{array}$ & $\begin{array}{l}\text { Distance from } \\
\text { tumors to } \\
\text { entry site }(\mathrm{cm})\end{array}$ & $\begin{array}{l}\text { Technical } \\
\text { success, } \\
\% \text { (n) }\end{array}$ & $\begin{array}{l}\text { Complete } \\
\text { resection, } \\
\% \text { (n) }\end{array}$ & $\begin{array}{l}\text { Complications } \\
\text { rate, } \% \text { (n) }\end{array}$ & $\begin{array}{l}\text { Additional } \\
\text { surgery, } \\
\% \text { (n) }\end{array}$ \\
\hline $\begin{array}{l}\text { Lee } \\
(2012)^{23}\end{array}$ & Korea & I & $\begin{array}{l}\text { Stomach } \\
\text { (body) }\end{array}$ & 16 & MP & 4 & $100(1)$ & $100(1)$ & $0(0)$ & 0 \\
\hline $\begin{array}{l}\text { Inoue } \\
(2012)^{24}\end{array}$ & Japan & 9 & $\begin{array}{l}\text { Esophagus, } \\
\text { stomach } \\
\text { (cardia) }\end{array}$ & 29.4 & MP & 5 & $77.8(7)$ & $85.7(6)$ & $0(0)$ & $22.2(2)^{\#}$ \\
\hline $\begin{array}{l}\mathrm{Xu} \\
(20 \mid 2)^{25}\end{array}$ & $\begin{array}{l}\text { People's } \\
\text { Republic of } \\
\text { China }\end{array}$ & 15 & $\begin{array}{l}\text { Esophagus, } \\
\text { stomach }\end{array}$ & 19 & MP & 5 & $100(15)$ & $100(15)$ & $13.3(2)$ & 0 \\
\hline $\begin{array}{l}\text { Gong } \\
(2012)^{26}\end{array}$ & $\begin{array}{l}\text { People's } \\
\text { Republic of } \\
\text { China }\end{array}$ & 12 & $\begin{array}{l}\text { Esophagus, } \\
\text { stomach } \\
\text { (cardia) }\end{array}$ & 19.5 & MP & 5 & $100(12)$ & $83.3(10)$ & $16.7(2)$ & 0 \\
\hline $\begin{array}{l}\text { Ye } \\
(20 \mid 4)^{27}\end{array}$ & $\begin{array}{l}\text { People's } \\
\text { Republic of } \\
\text { China }\end{array}$ & 85 & $\begin{array}{l}\text { Esophagus, } \\
\text { stomach }\end{array}$ & 19.2 & MP & 5 & $100(85)$ & $100(85)$ & 9.4 (8) & 0 \\
\hline $\begin{array}{l}\text { Wang } \\
(2013)^{28}\end{array}$ & $\begin{array}{l}\text { People's } \\
\text { Republic of } \\
\text { China }\end{array}$ & 18 & Esophagus & 33 & - & $\begin{array}{l}\text { Approximately } \\
3-5\end{array}$ & $13(100)$ & $100(18)$ & $16.7(3)$ & 0 \\
\hline
\end{tabular}

Note: ${ }^{\#}$ Giant tumor $>6 \mathrm{~cm}$, two patients.

Abbreviations: $\mathrm{Gl}$, gastrointestinal; MP, muscularis propria. 
Table 3 Clinical outcomes of tissue sampling methods for Gl subepithelial tumors

\begin{tabular}{|c|c|c|c|c|c|c|c|c|c|}
\hline $\begin{array}{l}\text { Author } \\
\text { (year) }\end{array}$ & Method & Country & $\begin{array}{l}\text { \# of } \\
\text { lesions }\end{array}$ & Location & $\begin{array}{l}\text { Mean } \\
\text { tumor } \\
\text { maximum } \\
\text { size }(\mathrm{mm})\end{array}$ & $\begin{array}{l}\text { Rate of overall } \\
\text { diagnosis } \\
(\text { cytology) } \\
\%(n)\end{array}$ & $\begin{array}{l}\text { Rate of overall } \\
\text { final definitive } \\
\text { diagnosis }(I H)^{*} \\
\%(n)\end{array}$ & $\begin{array}{l}\text { Major } \\
\text { complications } \\
\text { rate \% (n) }\end{array}$ & $\begin{array}{l}\text { Minor } \\
\text { complications } \\
\text { rate } \%(n)\end{array}$ \\
\hline Gress $(1997)^{33}$ & EUS-FNA & US & 27 & $\mathrm{Gl}$ tract & 27 & 81 (22) & - & $0(0)$ & $0(0)$ \\
\hline Ando $(2002)^{34}$ & EUS-FNA & Japan & 23 & Gl tract & 35.5 & $91(21)$ & $91(21)$ & $0(0)$ & $0(0)$ \\
\hline Hoda $(2009)^{36}$ & EUS-FNA & US & 112 & Upper Gl & 28.5 & $83.9(94)$ & $61.6(10)$ & $0(0)$ & $0(0)$ \\
\hline Mekky $(2010)^{37}$ & EUS-FNA & Japan & $|4|$ & Stomach & 29.9 & $82.3(116)$ & $34(48)$ & $0(0)$ & $0(0)$ \\
\hline $\begin{array}{l}\text { Fernández- } \\
\text { Esparrach } \\
(2010)^{38}\end{array}$ & EUS-TCB ${ }^{\#}$ & Spain & 40 & Upper Gl & - & $60(24)$ & $55(22)$ & - & - \\
\hline Lee $(2010)^{39}$ & EPR-UT & Korea & 16 & Upper Gl & 16.3 & $93.7(15)$ & $93.7(15)$ & $0(0)$ & 56 (9), oozing \\
\hline $\begin{array}{l}\text { de la Serna- } \\
\text { Higuera } \\
(201 \mathrm{I})^{40}\end{array}$ & SINK & Spain & 14 & Upper Gl & 31.2 & $92.8(13)$ & $78.6(1 \mathrm{I})$ & $0(0)$ & $0(0)$ \\
\hline $\begin{array}{l}\text { Binmoeller } \\
(2013)^{41}\end{array}$ & SLUB & US & 24 & Gl tract & 10 & $100(24)$ & $100(24)$ & $0(0)$ & $\begin{array}{l}8.3(2) \\
\text { abdominal pain }\end{array}$ \\
\hline $\begin{array}{l}\text { Kobara } \\
(2013)^{43}\end{array}$ & TBB & Japan & 8 & Upper Gl & 20.3 & $100(8)$ & $100(8)$ & $0(0)$ & $0(0)$ \\
\hline
\end{tabular}

Notes: "Rate of overall diagnosis including cytologic identification of suspicious (spindle) cells; ${ }^{*}$ rate of overall definitive diagnosis including IH analysis.

Abbreviations: EUS-TCB, endoscopic ultrasound-guided Tru-Cut biopsy using 19-gauge core needle; EUS-FNA, endoscopic ultrasound-guided fine-needle aspiration; EPR-UT, endoscopic partial resection using the unroofing technique; SINK, single-incision needle-knife; SLUB, suck ligate unroof biopsy; TBB, tunneling bloc biopsy using submucosal endoscopy with a mucosal flap; Gl, gastrointestinal; $\mathrm{lH}$, immunohistochemistry.

only $40 \%$ of gastric SETs not being GISTs. ${ }^{23-30}$ In contrast, almost all SETs located in the esophagus were leiomyomas, with GISTs being quite rare.

According to major guidelines, GISTs with malignant potential should be generally resected regardless of the tumor size. ${ }^{31,32}$ Indications for benign tumor resection should be based on clinical symptoms caused by GI obstruction resulting from large tumor size and the frequency of GISTs at each location, thus avoiding unnecessary surgery. Prior to resection, an optimal tissue sampling method is needed to diagnose SETs, thereby determining the most appropriate management plan, such as tumor resection or observation. In the future, each organ will be managed individually.

Our experience with resection of SETs located in the esophagogastric junction suggested that tumor enucleation using the submucosal tunneling technique would be optimal for SETs appearing on endoscopic ultrasound (EUS) as a hypoechoic, heterogeneous mass originating in the submucosal layer (Figure 1). This method yielded good results with no complications such as bleedings, perforations, and postoperative severe stenosis, suggesting that this method is appropriate for patients expected to experience postoperative symptoms or stenosis. However, extension of this application to SETs originating in the muscularis propria requires the formulation of a safe and appropriate method owing to the risks of perforation, bleeding, and tumor spillage into the peritoneal cavity.

\section{Tissue sampling method for subepithelial tumors}

Because approximately $50 \%$ of endoscopic resections are performed on benign SETs, better diagnosis of SETs is required; of the tissue sampling methods proposed for the diagnosis of SETs, EUS-guided fine-needle aspiration (EUS-FNA) has emerged as the standard (Table 3 ). However, the diagnostic ability of EUS-FNA is often limited by insufficient tissue for immunohistochemistry (IH). Therefore, new techniques with greater diagnostic yield are needed to acquire adequate specimens for immunohistochemical analysis.

\section{EUS-FNA}

EUS-FNA has become the standard method of obtaining tissue samples for the accurate diagnosis of GI SETs, ${ }^{31-34}$ as it is relatively rapid and convenient. Moreover, EUS-FNA is considered relatively safe, with complications, including bleeding and infection, being rare $(0 \%-2.6 \%) .{ }^{35}$ Based on the cytologic detection of suspicious (spindle) cells, the overall diagnostic rate of EUS-FNA was satisfactory $(>80 \%){ }^{33,34,36,37}$ However, the immunohistological analysis needed for a definitive diagnosis, including immunostaining such as CD34, c-KIT, $\alpha$-smooth muscle actin, and desmin showed that EUS-FNA had a much 

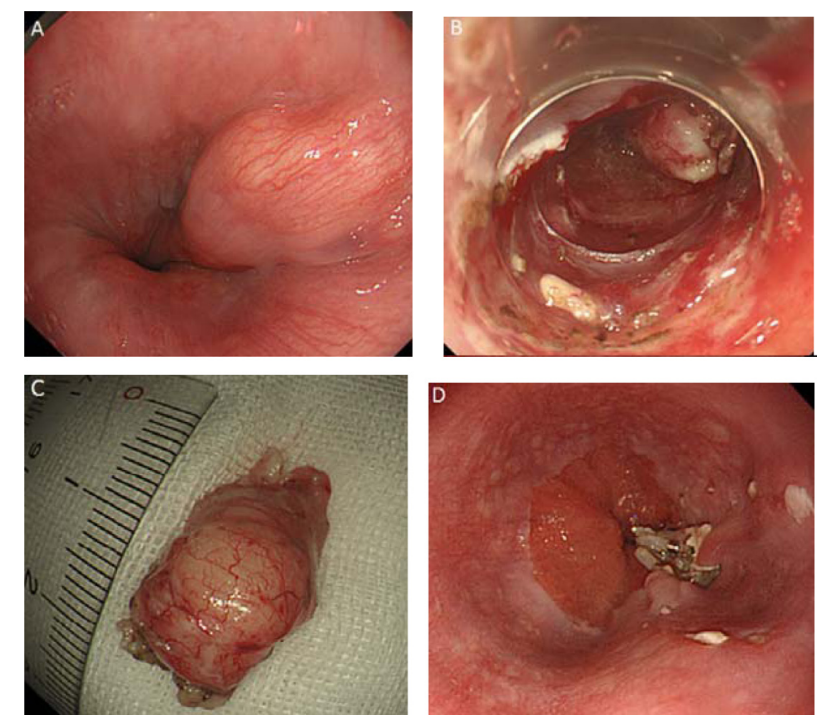

Figure I Endoscopic findings using submucosal tunneling technique of tumor enucleation in a SET located in the esophagogastric junction.

Notes: (A) Endoscopic finding showed a flat elevated subepithelial lesion in the esophagogastric junction, which might lead to stenosis by enlargement of the tumor in the future. (B) After making an entry site at $2 \mathrm{~cm}$ from the tumor's edge, a submucosal tunnel was created by submucosal dissection using a needle-knife form. After the tumor was identified and exposed in the tunnel, submucosa around the tumor was dissected. A white-colored tumor in the submucosal layer was enucleated completely. Finally, the entry site was sutured completely with hemoclips. (C) Macroscopic image of the resected specimen $(20 \times 12 \mathrm{~mm})$. IH findings resulted in a gastric leiomyoma. (D) Follow-up endoscopy 2 weeks after operation revealed no tumor or esophagogastric stenosis.

Abbreviations: SET, subepithelial tumor; IH, immunohistological.

lower diagnostic rate (34\%-61.6\%). ${ }^{36,37}$ Advanced EUS-guided Tru-Cut ${ }^{\circledR}$ (Quick-Core, Wilson-Cook Medical Inc, WinstonSalem, NC, USA) biopsy using a 19-gauge needle was not superior to EUS-FNA in the diagnosis of GISTs, because of the high technical failure rate of Tru-Cut ${ }^{\circledR}$ biopsies. ${ }^{38}$

\section{Endoscopic mucosal resection method}

Endoscopic partial resection using the unroofing technique (EPR-UT) has been used to collect tissue samples from SETs. ${ }^{39}$ Despite its high diagnostic yield, however, this method is not always safe, with a preliminary case series reporting a high rate $(56 \%)$ of bleeding secondary to snaring.

\section{Endoscopic linear incision method}

EUS-guided single-incision needle-knife (SINK) biopsy has been reported to be an easy and safe method of sampling from SETs ${ }^{40}$ This method has a high histological yield and may represent a reliable alternative to EUS-FNA for smaller subepithelial lesions. Using a single incision, and without submucosal dissection or complications, a histological diagnosis was reached in 13 of 14 patients. In that study, the size and morphologic characteristics of the lesions were first evaluated by EUS, and a pulsed Doppler scan was performed to scan for blood vessels in the area of the tumor. Using a needle knife, a 6-12 mm linear incision was made on the highest protrusion of the subepithelial tumor, and a regular biopsy forceps was introduced through this incision to obtain three to five biopsy samples for histopathological evaluation. Prophylactic clips were placed over the incision. Although a SINK biopsy may be convenient and safe, the specimens acquired using biopsy forceps may be insufficient for IH analysis.

A similar technique for the diagnosis and treatment of small subepithelial lesions involves suction of the lesion into a cap, ligation below the tumor, unroofing of the mucosa overlying the subepithelial tumor with a needle-knife, and biopsies from the exposed tumor. ${ }^{41}$ This technique, called "suck ligate unroof biopsy" (SLUB), may be safe and effective in obtaining sufficient tissue for IH but is useful only for sampling small SETs ( $<2 \mathrm{~cm}$ in diameter).

\section{Submucosal tunneling bloc biopsy}

We previously developed a bloc biopsy method, involving SEMF, called "tunneling bloc biopsy" (TBB), to obtain core biopsy specimens under direct vision from growing endoluminal SETs (Figure 2). ${ }^{42,43}$ This TBB method is technically advantageous, in that, upon completion of submucosal dissection after tunneling into the submucosa, the tumor can be visually identified, enabling reliable collection of a single bloc specimen adequate for IH analysis. This TBB method consists of four major procedures: ESD; creation of a short mucosal flap; bloc biopsy to acquire a specimen of sufficient size (approximately $5 \mathrm{~mm}$ ); and clip closure of the flap. Our preliminary evaluation in eight patients showed that the entire procedure was successfully completed without any complications and the rate of IH diagnosis was $100 \% .{ }^{43}$ These results suggested that this method, involving use of the SEMF method, is safe and effective for collecting tissue samples for pathologic diagnosis and for evaluating the malignant potential of SETs, even small lesions $(<2 \mathrm{~cm}$ in diameter). We are currently evaluating whether TBB improves final definitive diagnosis without adverse events when compared with standard EUS-FNA in the same patients.

In summary, tumors $<2 \mathrm{~cm}$ and apparently malignant should be treated using a mucosal incision method, such as SINK or TBB. If the tumor is larger than $2 \mathrm{~cm}$ in size, EUS-FNA may be sufficient for a final diagnosis, followed by SINK or TBB if necessary. The further development of appropriate tissue sampling methods for GI SETs will help avoid invasive and unnecessary resections. 


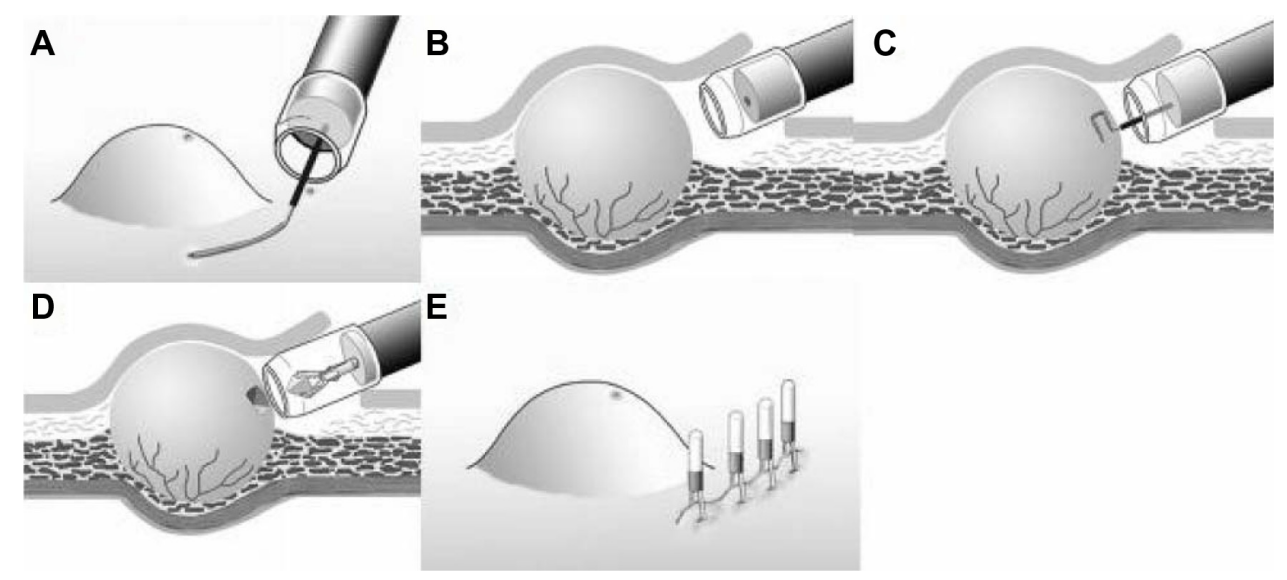

Figure 2 TBB procedure using submucosal endoscopy with the mucosal flap method for Gl subepithelial tumors.

Notes: (A) Endoscopic submucosal dissection: a $10 \mathrm{~mm}$ opening flap was created by mucosal incision and submucosal dissection. (B) SEMF: a short tunnel approaching the tumor was created by additional submucosal dissection. (C) Bloc biopsy: a bloc specimen, measuring $5 \times 5 \times 2$ mm, was obtained using a needle-knife and the cutting mode of the electrosurgical unit. (D) Tissue collection into a transparent cap. Specimen was removed into a long attachment, using grasping forceps. (E) Clip closure of flap. Opening flap was completely closed with hemoclips.

Abbreviations: TBB, tunneling bloc biopsy; GI, gastrointestinal; SEMF, submucosal endoscopy with mucosal flap.

\section{Functional and motility disorders}

Neurogastroenterology is defined as the neurology of the GI tract, involving the liver, gallbladder, and pancreas, and involves the control of digestion through the enteric nervous system, the central nervous system, and integrative centers in sympathetic ganglia. ${ }^{44}$ The submucosal tunneling technique enables endoscopic access to deeper tissue layers. Use of the probe-based confocal laser endomicroscopy (pCLE) provides optical histologic imaging of the site. Use of pCLE for submucosal access to the tumor site was successful in 17 of 17 sites (100\%). In animal models, pCLE could visualize the muscularis propria at 20 of 24 sites $(83.3 \%)$ and neuronlike cells at ten of 24 sites $(41.7 \%) .{ }^{45}$ Moreover, pCLE has been clinically applied to human patients. ${ }^{46}$ This new imaging approach may be of tremendous diagnostic importance in better characterizing and understanding functional and motility disorders.

\section{Conclusion}

This review has described current endoscopic interventions using submucosal tunneling techniques, which have produced excellent outcomes in animal models and in human patients. These methods, including NOTES and POEM, have been successfully used in patients with GI SETs, and functional and motility disorders.

Additional studies are needed to assess the advantages and disadvantages of these new techniques when compared with previous techniques such as surgical interventions. Factors influencing the use of these methods should include patient status, the ability of endoscopists, and the possibilities of tumor seeding and bacterial infection. Further studies and discussions should promote continued efforts to evaluate the clinical usefulness of these techniques, thus contributing to the endoscopic development of a multidisciplinary approach.

\section{Disclosure}

The authors report no conflicts of interest in this work.

\section{References}

1. Karita M, Tada M, Okita K, Kodama T. Endoscopic therapy for early colon cancer: the strip biopsy resection technique. Gastrointest Endosc. 1991;37(2):128-132.

2. Inoue H, Takeshita K, Hori H, Muraoka Y, Yoneshima H, Endo M. Endoscopic mucosal resection with a cap-fitted panendoscope for esophagus, stomach, and colon mucosal lesions. Gastrointest Endosc. 1993;39(1):58-62.

3. Ono H. Endoscopic submucosal dissection for early gastric cancer. Chin J Dig Dis. 2005;6(3):119-121.

4. Fujishiro M, Yahagi N, Nakamura M, et al. Successful outcomes of a novel endoscopic treatment for GI tumors: endoscopic submucosal dissection with a mixture of high-molecular-weight hyaluronic acid, glycerin, and sugar. Gastrointest Endosc. 2006;63(2):243-249.

5. Probst A, Pommer B, Golger D, Anthuber M, Arnholdt H, Messmann H. Endoscopic submucosal dissection in gastric neoplasia - experience from a European center. Endoscopy. 2010;42(12):1037-1044.

6. ASGE/SAGES. ASGE/SAGES Working Group on Natural Orifice Translumenal Endoscopic Surgery. White Paper October 2005. Gastrointest Endosc. 2006;63(2):199-203.

7. Kalloo AN, Singh VK, Jagannath SB, et al. Flexible transgastric peritoneoscopy: a novel approach to diagnostic and therapeutic interventions in the peritoneal cavity. Gastrointest Endosc. 2004;60(1):114-117.

8. Park PO, Bergström M, Ikeda K, Fritscher-Ravens A, Swain P. Experimental studies of transgastric gallbladder surgery: cholecystectomy and cholecystogastric anastomosis (videos). Gastrointest Endosc. 2005;61(4):601-606.

9. Mori H, Kobara H, Kobayashi M, et al. Establishment of pure NOTES procedure using a conventional flexible endoscope: review of six cases of gastric gastrointestinal stromal tumors. Endoscopy. 2011;43(7): 631-634. 
10. Inui K. Natural orifice transluminal endoscopic surgery: a step toward clinical implementation? Gastrointest Endosc. 2007;65(4):694-695.

11. Sumiyama K, GostoutCJ, RajanE, BakkenTA, KnipschieldMA, Marler RJ. Submucosal endoscopy with mucosal flap safety valve. Gastrointest Endosc. 2007;65(4):688-694.

12. Sumiyama K, Gostout CJ, Rajan E, et al. Transgastric cholecystectomy: transgastric accessibility to the gallbladder improved with the SEMF method and a novel multibending therapeutic endoscope. Gastrointest Endosc. 2007;65(7):1028-1034.

13. Sumiyama K, Gostout CJ, Rajan E, et al. Pilot study of transesophageal endoscopic epicardial coagulation by submucosal endoscopy with the mucosal flap safety valve technique (with videos). Gastrointest Endosc. 2008;67(3):497-501.

14. Yoshizumi F, Yasuda K, Kawaguchi K, Suzuki K, Shiraishi N, Kitano S. Submucosal tunneling using endoscopic submucosal dissection for peritoneal access and closure in natural orifice transluminal endoscopic surgery: a porcine survival study. Endoscopy. 2009; 41(8):707-711.

15. Pasricha PJ, Hawari R, Ahmed I, et al. Submucosal endoscopic esophageal myotomy: a novel experimental approach for the treatment of achalasia. Endoscopy. 2007;39(9):761-764.

16. Inoue $\mathrm{H}$, Minami $\mathrm{H}$, Kobayashi $\mathrm{Y}$, et al. Peroral endoscopic myotomy (POEM) for esophageal achalasia. Endoscopy. 2010;42(4):265-271.

17. Zhou PH, Cai MY, Yao LQ, et al. [Peroral endoscopic myotomy for esophageal achalasia: report of 42 cases]. Zhonghua Wei Chang Wai Ke Za Zhi. 2011;14(9):705-708. [Chinese].

18. von Renteln D, Inoue H, Minami H, et al. Peroral endoscopic myotomy for the treatment of achalasia: a prospective single center study. $\mathrm{Am} \mathrm{J}$ Gastroenterol. 2012;107(3):411-417.

19. Costamagna G, Marchese M, Familiari P, Tringali A, Inoue H, Perri V. Peroral endoscopic myotomy (POEM) for oesophageal achalasia: preliminary results in humans. Dig Liver Dis. 2012;44(10): $827-832$.

20. Minami H, Isomoto H, Yamaguchi N, et al. Peroral endoscopic myotomy for esophageal achalasia: clinical impact of 28 cases. Dig Endosc. 2014;26(1):45-51.

21. Lee BH, Shim KY, Hong SJ, et al. Peroral endoscopic myotomy for treatment of achalasia: initial results of a korean study. Clin Endosc. 2013;46(2):161-167.

22. Von Renteln D, Fuchs KH, Fockens P, et al. Peroral endoscopic myotomy for the treatment of achalasia: an international prospective multicenter study. Gastroenterology. 2013;145(2):309-311.

23. Lee CK, Lee SH, Chung IK, et al. Endoscopic full-thickness resection of a gastric subepithelial tumor by using the submucosal tunnel technique with the patient under conscious sedation (with video). Gastrointest Endosc. 2012;75(2):457-459.

24. Inoue H, Ikeda H, Hosoya T, et al. Submucosal endoscopic tumor resection for subepithelial tumors in the esophagus and cardia. Endoscopy 2012;44(3):225-230.

25. Xu MD, Cai MY, Zhou PH, et al. Submucosal tunneling endoscopic resection: a new technique for treating upper GI submucosal tumors originating from the muscularis propria layer (with videos). Gastrointest Endosc. 2012;75(1):195-199.

26. Gong W, Xiong Y, Zhi F, Liu S, Wang A, Jiang B. Preliminary experience of endoscopic submucosal tunnel dissection for upper gastrointestinal submucosal tumors. Endoscopy. 2012;44(3):231-235.

27. Ye LP, Zhang Y, Mao XL, Zhu LH, Zhou X, Chen JY. Submucosal tunneling endoscopic resection for small upper gastrointestinal subepithelial tumors originating from the muscularis propria layer. Surg Endosc. 2014;28(2):524-530.

28. Wang L, Ren W, Zhang Z, Yu J, Li Y, Song Y. Retrospective study of endoscopic submucosal tunnel dissection (ESTD) for surgical resection of esophageal leiomyoma. Surg Endosc. 2013;27(11):4259-4266.
29. Lee IL, Lin PY, Tung SY, Shen CH, Wei KL, Wu CS. Endoscopic submucosal dissection for the treatment of intraluminal gastric subepithelial tumors originating from the muscularis propria layer. Endoscopy. 2006;38(10):1024-1028.

30. Hwang JC, Kim JH, Kim JH, et al. Endoscopic resection for the treatment of gastric subepithelial tumors originated from the muscularis propria layer. Hepatogastroenterology. 2009;56(94-95):1281-1286.

31. Demetri GD, Benjamin RS, Blanke CD, et al; NCCN Task Force. NCCN Task Force report: management of patients with gastrointestinal stromal tumor (GIST) - update of the NCCN clinical practice guidelines. $J$ Natl Compr Canc Netw. 2007;5 Suppl 2:S1-S29.

32. Casali PG, Jost L, Reichardt P, Schlemmer M, Blay JY; ESMO Guidelines Working Group. Gastrointestinal stromal tumours: ESMO clinical recommendations for diagnosis, treatment and follow-up. Ann Oncol. 2009;20 Suppl 4:64-67.

33. Gress FG, Hawes RH, Savides TJ, Ikenberry SO, Lehman GA. Endoscopic ultrasound-guided fine-needle aspiration biopsy using linear array and radial scanning endosonography. Gastrointest Endosc. 1997;45(3):243-250.

34. Ando N, Goto H, Niwa Y, et al. The diagnosis of GI stromal tumors with EUS-guided fine needle aspiration with immunohistochemical analysis. Gastrointest Endosc. 2002;55(1):37-43.

35. O'Toole D, Palazzo L, Arotçarena R, et al. Assessment of complications of EUS-guided fine-needle aspiration. Gastrointest Endosc. 2001;53(4): 470-474.

36. Hoda KM, Rodriguez SA, Faigel DO. EUS-guided sampling of suspected GI stromal tumors. Gastrointest Endosc. 2009;69(7):1218-1223.

37. Mekky MA, Yamao K, Sawaki A, et al. Diagnostic utility of EUS-guided FNA in patients with gastric submucosal tumors. Gastrointest Endosc. 2010;71(6):913-919.

38. Fernández-Esparrach G, Sendino O, Solé M, et al. Endoscopic ultrasound-guided fine-needle aspiration and trucut biopsy in the diagnosis of gastric stromal tumors: a randomized crossover study. Endoscopy. 2010;42(4):292-299.

39. Lee CK, Chung IK, Lee SH, et al. Endoscopic partial resection with the unroofing technique for reliable tissue diagnosis of upper GI subepithelial tumors originating from the muscularis propria on EUS (with video). Gastrointest Endosc. 2010;71(1):188-194.

40. de la Serna-Higuera C, Pérez-Miranda M, Díez-Redondo P, et al. EUSguided single-incision needle-knife biopsy: description and results of a new method for tissue sampling of subepithelial GI tumors (with video). Gastrointest Endosc. 2011;74(3):672-676.

41. Binmoeller KF, Shah JN, Bhat YM, Kane SD. Suck-ligate-unroofbiopsy by using a detachable 20-mm loop for the diagnosis and therapy of small subepithelial tumors (with video). Gastrointest Endosc. Epub November 12, 2013

42. Kobara H, Mori H, Fujiwara S, Nishiyama N, Kobayashi M, Masaki T. Bloc biopsy by tunneling method using the endoscopic submucosal dissection for an upper gastrointestinal submucosal tumor. Endoscopy. 2012;44 Suppl 2 UCTN:E197-E198.

43. Kobara H, Mori H, Fujihara S, et al. Bloc biopsy by using submucosal endoscopy with a mucosal flap method for gastric subepithelial tumor tissue sampling (with video). Gastrointest Endosc. 2013;77(1): 141-145.

44. Furness JB. The enteric nervous system and neurogastroenterology. Nat Rev Gastroenterol Hepatol. 2012;9(5):286-294.

45. Ohya TR, Sumiyama K, Takahashi-Fujigasaki J, Dobashi A, Saito S, Tajiri H. In vivo histologic imaging of the muscularis propria and myenteric neurons with probe-based confocal laser endomicroscopy in porcine models (with videos). Gastrointest Endosc. 2012;75(2):405-410.

46. Sumiyama K, Kiesslich R, Ohya TR, Goetz M, Tajiri H. In vivo imaging of enteric neuronal networks in humans using confocal laser endomicroscopy. Gastroenterology. 2012;143(5):1152-1153. 


\section{Publish your work in this journal}

Clinical and Experimental Gastroenterology is an international, peerreviewed, open access journal, publishing all aspects of gastroenterology in the clinic and laboratory, including: Pathology, pathophysiology of gastrointestinal disease; Investigation and treatment of gastointestinal disease; Pharmacology of drugs used in the alimentary tract;
Immunology/genetics/genomics related to gastrointestinal disease. This journal is indexed on CAS. The manuscript management system is completely online and includes a very quick and fair peer-review system. Visit http://www.dovepress.com/testimonials.php to read real quotes from published authors.

Submit your manuscript here: http://www.dovepress.com/clinical-and-experimental-gastroenterology-journal 